\title{
Islamic Studies in South Africa
}

\section{Background of South African Islam}

In 1994, South Africans will celebrate three centuries of Islam in South Africa. Credit for establishing Islam in South Africa is usually given to Sheikh Yusuf, a Macasser prince who was exiled to South Africa for leading the resistance against the Dutch colonization of Malaysia. The first Muslims in South Africa, however, were actually slaves who had been imported, beginning in 1677, mainly from India, the Indonesian archipelago, Malaysia, and Sri Lanka, by the Dutch colonists living in the Cape. The Cape Muslim community, popularly but inaccurately known as "Malays" and known under apartheid as "Coloreds," is the oldest Muslim community in South Africa. The other major Muslim community was established over a century later by indentured laborers and tradespeople from northern India, a minority of whom were Muslims. The majority of South African Indian Muslims, classified as "Asians" or "Asiatics," now live in Natal and Transvaal. The third ethnically identifiable group, classified as "African" or "Black," consists mainly of converts or their descendants. Of the entire South African Muslim population, roughly 49 percent are "Coloreds," nearly 47 percent are "Asians," and, although statistics regarding "Africans" are generally unreliable, it is estimated that they are less than 4 percent. Less than 1 percent is "White."

\section{Contributions to South African Society}

Although Muslims make up less that 2 percent of the total population, their presence is highly visible. There are over twenty-five mosques in Cape Town and over one hundred in Johannesburg, making minarets as familiar as church towers. Many are historic and/or architectural monuments. More importantly, Muslims are uniquely involved in the nation's culture and economy. The oldest extant Afrikaans-language manuscripts are in the Arabic script, for they are the work of Muslim slaves writing in the Dutch patois. South African historian Achmat Davids has traced many linguistic elements of Afrikaans, both in vocabulary and grammar, to the influence of the Cape Muslims. Economically, the Indian Muslims are the most affluent, owing primarily to the circumstances under which they came to South Africa. Muslim names on businesses and buildings are a familiar sight in all major cities and on those university campuses that non-Whites were allowed to attend during apartheid. 
Perhaps most significant has been the Muslim contribution to the struggle against racism. Due to the communities' geographic and cultural separation, many early protests, such as the 1882 Revolt of the Malays, were communally based. The Natal Indians came together in 1930 to form the Natal Indian Congress for the express purpose of protesting a bill voiding their right to elect members of the Natal Legislative Assembly. The initiative for forming the Congress came from the Muslim community, although overall it was a joint Hindu-Muslim-Christian effort. The movement's leader, Mohandas Gandhi, was brought from India to South Africa by Muslims to be their lawyer. In his autobiography, Gandhi traced the awakening of his social and political consciousness and the development of his leadership skills to his experience among South Africa's Muslim Indians: "Here it was that the religious spirit within me became a living force ...." ${ }^{\prime 1}$ Gandhi is, of course, known for religious tolerance, and South African Muslims are proud of their close association with him. Dr. G. M. Karim, former director of education of the Islamic Council of South Africa, writes: "Perhaps the political world owes a debt to the Muslims for having contributed to the birth of the idea of passive resistance and its subsequent fulfillment in India!"2

Muslims have also been involved in South Africa's nationally based struggle. Following the Natal Indian Congress's successful passive resistance campaign in 1946, the African National Congress (ANC) decided to join forces with the Indians in the struggle to defeat racism and intolerance. Among the leading Muslims working with the ANC were Dr. Yusuf Dadoo, leader of the South African Indian Congress. In 1951, a joint planning council of the ANC and the Indian Congress was formed. Included on it were Dadoo and another officer of the Indian Congress, Yusuf Cachalia. Cachalia's brother, a life-long associate and trusted confidant of Gandhi, was also involved in the council, as were such other Muslim heroes of the struggle as Ahmed Kathrada, who was imprisoned for twenty-seven years and, after being released with Nelson Mandela, now heads the ANC's Public Relations Department. Ismail and Fatima Meer (Mandela's biographer) are well-known Muslim activists against apartheid and, like all who worked against that policy, have suffered detention, arrest, and torture. Today there are many Muslim leaders in the ANC, including Kader Asmal and Muhammad Valli Moosa, who was the ANC negotiator in the recently completed constitutional talks.

'Mohandas K. Gandhi, Autobiography: The Story of My Experiments with Truth, trans. by M. Desai (New York: Dover Publications).

${ }^{2}$ G. M. Karim, "The Contributions of Muslims to South African Culture," Bulletin on Islam and Christian-Muslim Relations in Africa 2, no. 1 (1984):6. 
There are also several specifically Muslim groups working for liberation and social justice. In 1961, Cape Muslims launched the Call of Islam to fight oppression and intolerance in the name of Islamic principles of social justice. Its leader, Imam Abdullah Haroon, was killed in detention in 1969 and became a renowned martyr for the antiapartheid cause. The original group was superseded by the Claremont Youth Movement (CYM), which later formed the Cape Islamic Federation (CIF) and remained devoted to the same principles. In 1970, the Muslim Youth Movement (MYM) was formed and later spun off the Muslim Students Association (MSA) in 1974 and at least ten other organizations, such as the Women's Islamic Movement and the Islamic Da'wah Movement. Qiblah, another Muslim group, was formed in 1980 and operated on the belief that by devoting itself to Islamic principles of social justice, it would be able to bring about liberation. The original Call of Islam movement no longer exists, but another Call of Islam was formed in the mid1980 s by former MYM and UDF (United Democratic Front) members. It remains at the forefront of Islamic social justice movements.

The 1970 s and 1980 s were a period of increased organizational activity and developing self-identity, particularly among young Muslims disenchanted with the conservatism of the older generations. These youth were also clearly inspired by the success of Islamic movements in the Middle East and Pakistan. Despite ideological and organizational differences, these and other smaller Muslim groups, which are motivated consciously by Islamic principles, are committed to the end of oppression and the establishment of a just society in South Africa.

\section{A Tradition of Tolerance}

One of the most striking characteristics of the South African Muslim community is its tradition of religious tolerance. This stands in marked contrast to the communal strife frequently associated with Islamic society in the modern Middle East and northern India. Several factors can be cited to explain this phenomenon. Most basically, the tolerance of South African Muslims is based on religious belief. Muslim activists of all varieties cite Qur'anic demands that believers fight injustice, regardless of who is being victimized. They further cite the Qur'an's pluralism: "Those who believe, Jews, Christians, and Sabaeans-whoever believes in God and the Last Day and does good works, they shall be rewarded and shall have nothing to fear" (2:62) and "If God had willed it, he would have made all of you one community" (5:48). Yusuf Saloojee, a physician who is both coordinator of the Call of Islam for the Transvaal and an executive of the ANC for Lenasia (Johannesburg), is currently involved 
in voter registration in the Muslim community. He reminds those who, having lived segregated for generations, question the wisdom of associating with non-Muslims that the overriding Islamic principle of unity (tawhid) requires not just belief in one God but working to reflect that belief by treating all of God's creatures as equal.

Beyond that, however, are the realities of South Africa's official policy of racism. As geographic segregation by skin color ignored religious differences, nonwhites of all religions tended to live and be educated together, which had an inevitable impact on social relations. Sophiatown, for example, was one of the oldest "Black" settlements in Johannesburg. When it was demolished, as a result of the Group Areas Act, it had a population of sixty thousand people. Like District 6 in Cape Town, it was home to people of color and all religions, and, though it was poor, it is remembered nostalgically as an ideal of communal living. Sophiatown has been immortalized in the work of Don Mattera, a popular South African poet, who speaks lovingly of its pluralism and religious tolerance. This proximity fostered solidarity among the oppressed. As Yusuf Cachalia said of the above-mentioned 1952 civil disobedience campaign: "No amount of police presence could dampen the enthusiasm with which the down-trodden masses supported the defiance campaign." ${ }^{3}$

\section{Muslim Education in South Africa}

The earliest Muslim community in South Africa, which was composed of slaves, was prohibited from practicing its religion openly. As a result, its members developed innovative religious associations based primarily on their indigenous South Asian Sufi practices. Such religious education as was carried on was in the home. In was not until the end of the eighteenth century that the first mosque, the Awwal Mosque on Dorp Street in Cape Town, was established. Attached to the mosque was the country's first Islamic school. Its founder, Tuan Guru ("Mister Teacher" in Malay; d. 1797), also trained the first group of imams in South Africa. ${ }^{4}$

In 1805, after England had wrested control of the Cape from the Dutch, Muslims were granted religious freedom. At that time, it was

${ }^{3}$ Heidi Holland, The Struggle: A History of the African National Congress (London and Glasgow: Grafton Books, 1990).

"Muhammed Haron, "Islamic Education in South Africa," The Muslim Educational Quarterly 5, no. 2 (1988):41. The information in the sections on "Muslim Education" and "Advanced Islamic Studies" is summarized from this article, which includes a useful bibliography, and information received from Professor Iqbal Jhazbhay, Department of Semitics, University of South Africa. 
thought important for the Cape Muslims to have a properly trained scholar for religious training. Sheikh Abu Bakr Effendi (d. 1880) was sent from Turkey. He established a girl's school and the School of Higher Islamic Theology and also produced the earliest work on Islam in ArabicAfrikaans: Bayān al Dīn (The Explanation of Religion).

Islamic schools that were independent of mosques were not established until the early twentieth century. Known as madrasah schools or Muslim mission schools, the first was established in 1912. By 1959, nineteen such schools, all of which followed the same curriculum as the secular schools and featured additional lessons in Islamic studies, had been established throughout the Cape and Natal. Many of them received government assistance, in the form of teachers' salaries, and enjoyed the same status as Christian missionary schools.

The imposition of apartheid in 1948 had a devastating effect on Muslim education, particularly after the passage of the Group Areas Act of 1950 , which forced the relocation of nonwhite people to areas reserved for their color classification. Most of the madrasahs had to be abandoned, though some were reestablished in the new areas. In the 1960s, new madrasahs began to be established. However, these were different from the earlier institutions that had paralleled secular schools, for they were afterschool religion programs designed to supplement public school education. Muslims were also successful in influencing the "Indian Affairs" and "Colored Affairs" education departments to introduce Islamic studies and Arabic in their public high schools in the 1970 s. In the 1980 s, some private Muslim high schools were established as well, usually under the patronage of wealthy families.

Efforts to unify the curriculum of Islamic education at the provincial level through associations of religious scholars are continuing. Difficulties arise at the national level, however, for two reasons. For one thing, the diverse ethnic origins of the Malay and Indian communities show themselves in both theoretical and practical issues. The Cape community, for example, generally follows the Shäfi' $\overline{1}$ madhhab and retains vestiges of some of South Asian Sufi practices, while the Natal and Transvaal communities tend to be Hanafi and influenced by either Deobandi or Brelvi thought as well as cultural practices dominant in their ancestral Indian regions of origin. These differences are particularly evident in the seventeen theological seminaries now in existence in South Africa, all of which operate independently of one another. Furthermore, the legacy of apartheid lingers. One of its effects, in addition to intensifying the ethnic identities of segregated groups, was the empowerment of regional religious leaders. Transcending apartheid-induced provincialism would require that some people relinquish their elite status. As in Muslim com- 
munities elsewhere, there is a great deal of talk about Islamic unity and condemnation of the divisions imposed by imperialism. But effective action on the part of existing provincial elites is difficult to discern.

\section{Advanced Islamic Studies in South Africa}

It is on the university level that the greatest progress has been made in promoting Arabic and Islamic studies. ${ }^{5}$ Since 1955, programs have been developed at the University of South Africa (a correspondence university that was the only university without skin-color requirements during apartheid), the University of Durban-Westville (formerly for "Asian" students), the University of Westem Cape (formerly for "Colored" students), as well as such formerly English and Afrikaaner universities as the University of Cape Town, the University of Natal, the University of Witwatersrand, the University of Orange Free State, the University of Pretoria, the University of Port Elizabeth, the University of Stellenbosch, Rand Afrikaans University, and Potchefstroom University. Many of those involved in the Islamic resurgence groups mentioned above are involved in or are products of these programs, particularly the ones at the University of South Africa, the University of Durban-Westville, the University of the Western Cape, and the University of Cape Town.

The number of theses on Islam and related subjects presented at South African universities at the undergraduate, master's, and doctoral levels has increased exponentially over the past two decades. Of a total of 192 produced since 1930,1 was done in the 1930s, 1 in the 1940 s, 5 in the $1950 \mathrm{~s}, 11$ in the $1960 \mathrm{~s}, 28$ in the $1970 \mathrm{~s}$, and 134 in the $1980 \mathrm{~s}$. The subjects range as follows: Arabic, Afrikaans-Arabic/Malay, Qur'anic studies, Islamic studies (general), biographies, social science studies on Muslim communities, education, Islamic politics, Islamic philosophy, Islamic history, Islamic law, missions, Islamic institutions and organizations, economics, the Middle East, Islamic art and architecture, and Islamic music. The majority have been in Arabic, Qur'anic studies, Islamic studies, Islamic institutions and organizations, and the Middle East. There is also a discernable trend toward studying Islam in South Africa rather than in the so-called central Islamic lands. Since 1970, ninety-six theses have focused on aspects of Islam in South Africa, compared to five before 1970 .

${ }^{5}$ It should be noted that the increased organizational activity of Muslims is also seen in a proliferation of newspapers and newsletters, journals, and community-based organizations as well. See Ebrahim Mohamed Mahida, Islam in South Africa: A Bibliography (Durban: Centre for Research in Islamic Studies, University of Durban-Westville, 1993). 
Among the effects of this emphasis on advanced Islamic studies in South Africa has been the production of locally trained religious leaders. Traditionally, South African religious scholars have been trained in the Middle East, India, Pakistan, or Malaysia. Graduates of foreign institutions tend to have greater prestige than those trained in local theological institutions. But this foreign training has tended both to intensify the ideological differences among Hanafi, Shāfi' $\overline{1}$, Deobandi, and Brelvioriented communities and to keep religious leaders focused on issues in Muslim-majority countries rather than in South Africa. At the same time, it has tended to orient the Muslim community's identity away from South Africa, which has created some tension between their Muslim identity and their South African identity. Many young scholars in South Africa today see the development of locally trained religious scholars as a first step toward the unification of the diverse Muslim communities in South Africa as well as working toward a harmonization of their religious and national identities.

\section{Conclusion}

South Africa's Muslim community has become increasingly selfconscious over the past twenty years. This is partly due to the influence of worldwide Islamic tendencies, particularly in the Middle East and the Indian subcontinent. It is also a result of the unique circumstances of South Africa's racist government. For over three hundred years, South African Muslims lived as an oppressed minority alongside but segregated from an oppressed majority. Thus they were involved in several levels of communal identity-Muslim, nonwhite, South African national-that were overlapping but differing in intensity, value, or duration. The racist status of inferiority was imposed from without and rejected from within. In addition, the nationalist South African identity is mixed with ethnic ties to ancestral homelands. Of the three levels of communal identity, only the religious has managed to withstand the vagaries of colonialism and postcolonialism.

But even religious identity is dynamic, capable of changing along with sociopolitical developments. South Africa's Muslim communities are making an historic transition from being segregated minorities opposed to an oppressive regime to being participants in an open and diverse society. The upsurge in Islamic studies in South African universities reflects their concern with facing the challenges posed by this transition: democratization, pluralism, the role of women, economic and labor issues, and the role of Muslims as a religious minority. In the process of facing these issues, the South African Muslim community is moving from the 
margins of the Islamic world. In the past, scholars tended to focus on Islamic-majority countries on the assumption that they are somehow more representative of Islam than minority Muslim communities. The increasingly high profile assumed by such minority communities as South Africa's presents scholars with an opportunity to evaluate the validity of that assumption. Regardless of how this and other methodological questions are addressed, however, the expanding scholarly output of South Africa's Muslim intellectual community will no doubt provide a valuable resource for those interested in issues faced by both Muslim minorities and majorities in a highly dynamic society.

Tamara Sonn

St. John Fisher College Rochester, New York 